\title{
STUDI POPULASI BAKTERI RESISTEN MERKURI DI DAERAH ALIRAN SUNGAI TONDANO, KELURAHAN KETANG BARU, MANADO
}

\author{
Aaltje E. Manampiring ${ }^{1)}$, Billy J. Keppel ${ }^{1)}$ \\ ${ }^{1)}$ Bagian Kimia Fakultas Kedokteran Universitas Sam Ratulangi, Manado 95115
}

\begin{abstract}
ABSTRAK
Kadar merkuri yang tinggi di perairan umumnya dapat mempengaruhi keadaan biota termasuk bakteri yang resisten terhadap merkuri. Penelitian deskriptif yang menggunakan metode cross sectional bertujuan untuk menguji resistensi bakteri di aliran sungai Tondano, Kelurahan Ketang Baru, Manado terhadap merkuri. Escherichia coli dan Bacillus careus (isolat1,1 dan 2,2) hanya dapar tumbuh pada konsentrasi $\mathrm{HgCl}_{2} 0,02 \%$. Lactobacillus sp. dan Veillonella parvula (isolat 1,2 $2,13,1$ dan 3,2) tumbuh pada konsentrasi $\mathrm{HgCl}_{2} 0,06 \%$. Lactobacillus $s p$. (isolat 3,1) saja yang tumbuh pada konsentrasi $\mathrm{HgCl}_{2} 0,1 \%$ dan tidak ada bakteri yang mampu tumbuh pada konsentrasi $\mathrm{HgCl}_{2} 0,2 \%$.
\end{abstract}

Kata kunci: bakteri, merkuri

\section{STUDY ON POPULATION OF MERCURY-RESISTANT BACTERIA IN THE WATERSHED AREA OF TONDANO RIVER, KELURAHAN KETANG BARU, MANADO}

\begin{abstract}
High concentration of mercury in the watershed area can affect biota condition, including mercury-resistant bacteria. This descriptive research with cross-sectional method aimed to evaluate the mercury-resistance of bacteria in watershed area of Tondano, Kelurahan Ketang Baru, Manado. Escherichia coli and Bacillus careus (isolates 1,1, dan 2,2) were able to grow in $\mathrm{HgCl}_{2}$ 0,02\%. Lactobacillus sp. and Veillonella parvula (isolates 1,2 2,1 3,1 and 3,2) grow in $\mathrm{HgCl}_{2}$ 0,06\%. Lactobacilus sp. (isolate 3,1) only grow in $\mathrm{HgCl}_{2} 0,1 \%$ and none of bacteria could grow in $\mathrm{HgCl}_{2} 0,2 \%$.
\end{abstract}

Keywords: bacteria, mercury

\section{PENDAHULUAN}

Logam merkuri diperoleh dari pengolahan bijihnya yang disebut Cinabar, dengan oksigen (anonim, 2009). Logam merkuri merupakan salah satu trace element yang mempunyai sifat cair pada temperatur ruang dengan spesifik gravity dan daya hantar listrik yang tinggi. Karena sifat-sifat tersebut, merkuri banyak digunakan baik dalam kegiatan perindustrian maupun laboratorium (Budiono, 2008).

Kadar merkuri yang tinggi pada perairan umumnya diakibatkan oleh buangan industri (industrial wastes) dan akibat sampingan dari penggunaan senyawa-senyawa merkuri di bidang pertanian. Terdapatnya merkuri di perairan dapat disebabkan oleh dua hal, yaitu pertama oleh kegiatan perindustrian seperti pabrik cat, pabrik emas, kertas, peralatan listrik, chlorine dan coustic soda; kedua oleh alam itu sendiri melalui proses pelapukan batuan dan peletusan gunung berapi. Karena sifatnya yang sangat beracun, maka U.S. Food and Administration (FDA) menentukan pembakuan atau Nilai Ambang Batas (NAB) kadar merkuri yang ada dalam jaringan tubuh badan air, yaitu sebesar 0,005 ppm (Budiono, 2008).

Merkuri di alam berada dalam tiga bentuk dasar, yaitu: merkuri metalik, merkuri anorganik dan merkuri organik (anonim, 2009; Budiono, 2008). ${ }^{2}$ Toksisitas Merkuri tergantung pada bentuknya di alam. Merkuri yang masuk ke tubuh pada akhirnya akan terakumulasi di dalam organ-organ tubuh dan mengakibatkan kerusakan bagi organ tersebut. Merkuri metalik dapat larut dalam lemak dan didistribusikan keseluruh tubuh. Merkuri metalik dapat menembus Blood- 
Brain Barier dan Placental Barier. Setelah menembus Blood-Brain Barier, merkuri metalik akan terakumulasi dalam otak. Sedangkan merkuri yang menembus Placental Barier akan merusak pertumbuhan dan perkembangan janin (anonim, 2009; anonim, 2008; Wardhana, 1994). Kasus keracunan merkuri pertama kali di laporkan di Jepang pada tahun 1953 - 1960, yang dikenal dengan kasus Minamata, dimana dilaporkan 100 orang cacat, 43 orang meninggal dan 119 Bayi lahir dengan cacat bawaan. Penyebabnya adalah limbah merkuri dari pabrik plastik yang dibuang ke laut dan ditemukan kadar merkuri yang tinggi pada ikan yaitu sebesar 27 - 102 ppm. Selain itu juga kasus di Irak tahun 1961 dimana 35 orang meninggal dan 321 orang cacat. Kasus serupa juga terjadi di Niigata, Jepang pada tahun 1965, dimana menurut laporan 26 orang keracunan dan 5 diantaranya meninggal (Wardhana, 1994; Noviani dan Gusarizal, 2004).

Penelitian tentang kadar merkuri sudah banyak dilakukan di Indonesia dan hasilnya banyak sungai yang mengandung merkuri diatas nilai normal (Wardhana, 1994). Penelitian tentang kadar merkuri di sungai sudah pernah dilakukan di Sulawesi Utara yaitu oleh Harun di Sungai Tondano di daerah Komo Luar dimana didapatkan kadar merkuri diatas nilai normal pada dua titik dari enam titik yang dijadikan sampel (Harun, 2008).

Merkuri di sungai ataupun daerah perairan dapat mempengaruhi keadaan biota yang ada di perairan tersebut (Budiono, 2008). Banyak biota yang terganggu ekosistemnya, tapi ada jenis bakteri yang ditemukan resisten terhadap merkuri, walaupun bakteri tersebut terpapar dengan merkuri dalam waktu yang lama, bakteri ini disebut bakteri resisten merkuri, dimana bakteri ini memiliki gen yang resisten. Umumnya terdiri atas gen metaloregulator (MerR), Gen Transport merkuri (MerT, MerP, MerC), Gen Merkuri reduktase (MerA) dan Organomerkuri liase (MerB) (Noviani dan Gusrizal, 2004).

Sudah banyak penelitian-penelitian sebelumnya tentang bakteri resisten merkuri. Penelitian sudah dilakukan diberbagai daerah, misalnya penelitian di Daerah Penambangan Emas di Kalimantan Selatan oleh Noviani dan Gusrizal (Noviani dan Gusrizal, 2004).
Penelitian serupa juga pernah dilakukan oleh Londah di daerah Teluk Manado, Sulawesi Utara (Londah, 2009).

Sungai Tondano yang merupakan salah satu sungai besar di Sulawesi Utara sering digunakan masyarakat sekitar untuk membuang hasil limbah rumah tangga maupun industri rumah tangga (home industry), dan menurut informasi dari masyarakat, di daerah aliran Sungai Tondano, tepatnya di Kelurahan Ketang Baru terdapat beberapa industri rumah tangga (menurut informasi, yang telah teridentifikasi terdapat lebih dari lima tempat) yang merupakan tempat penyepuhan dan pembakaran emas dengan menggunakan merkuri sedangkan limbahnya dibuang di sungai serta kegiatan ini dilakukan diam-diam pada malam hari. Dengan adanya informasi ini, dan juga belum adanya penelitian di daerah tersebut, maka penulis tertarik untuk melakukan penelitian agar dapat menentukan berapa kadar merkuri di daerah aliran sungai tersebut dan jika kadarnya diatas nilai normal dan adakah bakteri yang mampu bertahan hidup di lingkungan tersebut.

\section{METODE PENELITIAN}

Penelitian ini bersifat deskriptif yang menggunakan metode cross-sectional. Penelitian ini dilakukan di Kelurahan Ketang Baru Kota Manado pada bulan Mei-Agustus 2010. Populasi adalah bakteri yang hidup dalam sedimen di sepanjang aliran Sungai Tondano, dan sampel adalah bakteri yang terdapat pada sedimen dari tiga titik yang ada di daerah Ketang Baru.

Varibael penelitian yaitu kadar Merkuri, gambaran populasi bakteri, bakteri resisten Merkuri. Sampel yang diambil dari beberapa titik dilokasi pengambilan sampel selanjutnya dianalisis kadar merkuri dengan menggunakan instrument (Atonmic Absorption Spechtrophometry), dan kemudian dilakukan identifikasi bakteri dan uji resistensi.

\section{HASIL DAN PEMBAHASAN}

Penelitian yang dilakukan pada 3 titik dilokasi pengambilan sampel di daerah aliran sungai Tondano di Kelurahan Ketang Baru, ditemukan adanya kandungan merkuri pada sampel tersebut. Walaupun ketiga titik hanya berjarak 10 meter, namun terdapat perbedaan 
kadar merkuri, dimana didaerah karamba ikan (titik 1) dan titik 2 yang dicurigai tempat pembuangan limbah merkuri oleh industri penyepuhan emas, kadarnya lebih tinggi daripada di titik 3 dimana sampel diambil dibawah jembatan yang tidak berhubungan langsung dengan saluran pembuangan. Hal ini dimungkinkan karena merkuri merupakan logam berat yang akan mengendap lebih banyak pada tempat asal merkuri tersebut yaitu dari tempat pembuangan limbah, dan lebih jauh dari sumber maka merkuri akan mengalami pengenceran sehingga kadarnya akan lebih kecil daripada kadar di sumber pembuangan merkuri.

Setelah dilakukan analisa kadar merkuri pada sampel, tahap selanjutnya yang dilakukan adalah isolasi dan identifikasi bakteri yang meliputi uji morfologi, uji fisiologi dan uji biokimia. Setelah bakteri diisolasi dalam enam isolat yang terdiri dari dua isolat untuk masing-masing lokasi, maka segera dilakukan identifikasi terhadap bakteri di tiap isolat tersebut.

Isolat 1.1 menunjukkan gambaran bakteri Eschericia coli. Bakteri ini merupakan bakteri batang Gram negatif. Berukuran 1-3 $\mu$, bisa motil, tapi ada beberapa juga yang non motil. Koloni yang terbentuk pada agar miring berwarna putih keabuan dan menyebar dan bergelombang, pada nurtrien Broth, keruh, sedimen banyak terkumpul didasar dan berwarna keabuan. E. Coli merupakan bakteri aerob tapi juga bisa bersifat fakultatif anaerob. Katalase negatif. Uji indol positif. $\mathrm{H}_{2} \mathrm{~S}$ jarang terbentuk pada media yang sensitifitasnya rendah tetapi pada media yang lebih sensitif seperti TSIA, hasilnya dapat positif. Memfermentasikan glukosa. Merupakan bakteri yang resisten terhadap panas, media tumbuh optimum yaitu $30-37$ ${ }^{\circ} \mathrm{C}$ (Breed et. all.).

Isolat 1.2 dan 2.1 dan 3.2 menunjukkan gambaran bakteri Lactobacillus $s p$. Lactobacillus merupakan bakteri Gram positif, berbentuk batang, bisa motil, bisa juga non motil, bersifat anaerob, katalase negatif, biasanya ditemukan diusus halus mamalia termasuk manusia. Gambaran koloni pada agar datar biasanya terbentuk koloni yang kecil. Pada nutrien broth keruh. Memfermentasikan glukosa tanpa gas, temperatur maksimal $65{ }^{\circ} \mathrm{C}$ dan minimal $30^{\circ} \mathrm{C}$ (Breed et. all.).
Isolat 2.2 menunjukkan gambaran yang sesuai dengan Bacillus cereus yang merupakan bakteri batang Gram positif. Motil. Koloni yang terbentuk di agar padat adalah besar, tidak beraturan dan berwarna keputihan. Pada agar miring, koloni yang terbentuk berwarna keputihan, berbentuk opaque dan menyebar. Pada broth tampak berat, terkumpul didasar dan keruh. Dapat membentuk asam tapi tidak membentuk gas terutama dari glukosa, glycerol dan salisin. Memproduksi nitrit. Bersifat aerobik tapi juga dapat bersifat fakultatif anaerobik. Memerlukan asam amino untuk pertumbuhannya. Bisa hidup pada suhu $30{ }^{\circ} \mathrm{C}$ dan maksimum antara $37-48^{\circ} \mathrm{C}$. Habitatnya banyak tersebar di debu, tanah, susu dan permukaan tanah (Breed et. all.).

Isolat 3.1 menunjukkan gambaran bakteri Veillonella parvula, dim ana bakteri ini merupakan bakteri coccus Gram negatif yang sangat kecil dengan diameter 0,2-0,4 $\mu$. Pada agar miring, koloni yang terbentuk transparan, pada media pepton broth koloni yang terbentuk keruh. Bakteri memproduksi indol dan $\mathrm{H}_{2} \mathrm{~S}$. Menghasilkan asam dan gas dari glukosa, juga dari fruktosa, sukrosa, manitol, maltosa dan innulin. Selain itu juga memproduksi nitrit dari pemecahan nitrat, merupakan bakteri anaerob dan katalase negatif. Suhu optimum dapat tumbuh adalah $37{ }^{\circ} \mathrm{C}$, dan suhu minimal adalah $22{ }^{\circ} \mathrm{C} . \mathrm{pH}$ optimum adalah antara 6,5-8,0 (Breed et. all.).

Hasil identifikasi terhadap ke enam isolat, didapatkan empat jenis bakteri yang berbeda yaitu, Escherichia coli, Lactobacillus sp, Bacillus cereus dan Veillonella parvula. Hasil ini didapatkan setelah dicocokkan dengan buku Bergey's Manual Determinative of bacteriology.

Hasil yang didapatkan pada penelitian ini berbeda dengan hasil yang didapatkan oleh Noviani dan Gusrizal pada penelitian yang dilakukan di daerah penambangan Emas di Kalimantan Barat, dimana dari 18 isolat yang diuji hanya menemukan dua spesies bakteri yaitu Enterobacter hafniae dan Enterobacter cloaca (Noviani dan Gusrizal, 2004).

Uji resistensi menunjukkan bahwa semua bakteri masih dapat hidup pada konsentrasi

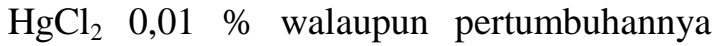
lebih lambat jika dibandingkan dengan pertumbuhan bakteri pada media yang kadar $\mathrm{HgCl}_{2}$ 0\%. Pada konsentrasi $\mathrm{HgCl}_{2} 0,02 \%$ 
pun semua bakteri masih dapat bertahan dengan baik. Tapi ketika konsentrasi $\mathrm{HgCl}_{2}$ ditingkatkan menjadi $0,06 \%$ sudah mulai ada yang mati yaitu E.coli dan Bacillus cereus. Sedangkan isolat 1.2,2.1, 3.1 dan 3.2 yang mengandung bakteri Lactobacilus sp dan Veillonella parvula masih dapat bertahan.

Ketika konsentrasi dinaikkan menjadi 0,1 $\%$, hanya 1 isolat yang masih bertumbuh yaitu isolat 3.2 yang mengandung bakteri Lactobacillus sp. Sedangkan pada konsentrasi $0,2 \%$ semua bakteri tidak dapat bertumbuh lagi.

Bakteri Lactobacillus pada isolat 3.2 adalah satu-satunya bakteri yang bertumbuh pada konsentrasi $\mathrm{HgCl}_{2} \quad 0,1 \%$ sedangkan pada isolat 1.2 dan 2.1 yang teridentifikasi dengan Lactobacillus tidak mengalami pertumbuhan. Hal ini dimungkinkan karena luasnya spesies lactobacillus yang tersebar di alam serta ada tidaknya gen resisten merkuri pada bakteri tersebut.

Suatu bakteri digolongkan bakteri resisten merkuri apabila bakteri tersebut dapat bertahan pada konsentrasi merkuri 0,01 ppm. Dari hasil penelitian hanya 1 bakteri yang mampu hidup pada kadar merkuri 0,1\% (100 ppm) sedangkan bakteri lainnya bertahan sampai konsentrasi merkuri 0,06\% (60 ppm).

Hasil yang didapatkan ini juga berbeda dengan hasil yang ditemukan oleh Noviani dan Gusrizal yang menemukan dari ke 18 isolat yang diperiksa dan 2 bakteri yang ditemukan, semua adalah bakteri yang resiten terhadap merkuri. Hal ini dapat terjadi karena sampel diambil dari daerah penambangan emas ilegal yang telah ada selama 6 tahun. Tingkat resistensi bakteri didaerah itu terhadap merkuri adalah $5,25 \mathrm{~g} / \mathrm{mL}$ (5250 ppb) (Noviani dan Gusrizal, 2004). Hasil ini sangat tinggi sehingga disimpulkan bakteri ini dapat bertahan karena bakteri ini memiliki gen resisten merkuri (Noviani dan Gusrizal, 2004; Canstein, et. all., 2002).

Perbedaan hasil tingkat resistensi bakteri terhadap merkuri pada kedua lokasi ini dapat disebabkan oleh berbagai macam faktor. Salah satunya adalah kadar merkuri. Keberadaan gen resisten merkuri sampel diduga berhubungan langsung dengan lamanya kandungan $\mathrm{Hg}$ pada lokasi penambangan. Tingginya kontaminasi $\mathrm{Hg}$ pada daerah tersebut akan menginduksi sel bakteri untuk menerima gen resisten merkuri dari lingkungan (Smit et al, 1998). Penelitian pada daerah aliran sungai Tondano di Kelurahan Ketang Baru hanya dapat menentukan tingkat resistensi bakteri terhadap merkuri, tetapi belum dapat menentukan apakah bakteri yang ditemukan memiliki gen resisten merkuri atau tidak. Untuk itu diperlukan penelitian lebih lanjut mengenai gen bakteri yang berhasil di identifikasi khususnya bakteri Lactobacillus $s p$ yang mampu tumbuh pada konsentrasi 0,1 $\%$ (100 ppm).

Penelitian bakteri resisten merkuri ini penting, terutama dalam upaya kesehatan masyarakat khususnya untuk dapat memutuskan rantai mekanisme keracunan merkuri. Penelitian ini bertujuan untuk mengurangi atau menghilangkan merkuri di lingkungan melalui upaya detoksifikasi merkuri di perairan.

\section{KESIMPULAN}

Hasil pemeriksaan kadar merkuri pada semua sampel dari 3 titik, tidak ditemukan kadar merkuri yang melebihi ambang batas yaitu $0,0004 \mathrm{mg} / \mathrm{L}$ pada titik 1 , $0,0004 \mathrm{mg} / \mathrm{L}$ pada titik 2 dan $0,0002 \mathrm{mg} / \mathrm{L}$ pada titik 3. Hasil identifikasi bakteri yang dilakukan pada 6 isolat bakteri didapatkan empat jenis bakteri yang berbeda yaitu Escherichia coli, Lactobacillus sp, Bacillus cereus dan Veillonella parvula. Hasil uji resistensi terhadap merkuri didapatkan 2 bakteri yang hanya bertahan sampai pada konsentrasi $\mathrm{HgCl}_{2} \quad 0,02 \%$ yaitu Escherichia coli dan Bacillus cereus (isolat 1.1 dan 2.2), dua bakteri yang dapat bertahan pada konsentrasi $\mathrm{HgCl}_{2} 0,06 \%$ yaitu Lactobacillus $s p$ dan Veillonella parvula (isolat 1.2, 2.1, 3.1 dan 3.2), serta hanya satu bakteri yang dapat bertahan pada konsentrasi $\mathrm{HgCl}_{2} 0,1 \%$ yaitu Lactobacilus sp (isolat 3.1), dan tidak ada bakteri yang mampu tumbuh pada konsentrasi $\mathrm{HgCl}_{2}$ 0,2\%.

\section{DAFTAR PUSTAKA}

Anonim. 2009. Forum Sains Indonesia (editorial). Efek Toksik Merkuri Metlik ( $\mathrm{HgO})$. Source http://www.forumsains.com/artikel/ efek-toksik-merkuri-metalik-hgo/ favicon.ico. diunduh 8 mei 2010. 
Anonim. 2008. Green Facts (editorial). Scientific facts on mercury. Source UNEP Global Mercury Assessment report, Summary of the Report,

Breed, R., E. Murray, N. Smith, et. al. 1957. Bergey's Manual of Determinative bacteriology. $7^{\text {th }}$ edition. The william and witkins company.

Budiono, A. 2008. Pengaruh Merkuri bagi biota Laut (Makalah Pengantar Falsafah Sains).

Canstein, H.V., Y. Li, J. Leonhauser, E. Haase, A. Felske, W.D. Deckwer, and I.W. Dobler. 2002. Spatially oscillating activity and microbial succession of mercury-reducing biofilms in a technical-scale bioremediation system. Appl. Environ. Microbiol. 68: 19381946.
Harun, F. 2008. Tinjauan Kadar Merkuri $(\mathrm{Hg})$ pada air sungai di Kelurahan Komo Luar. [Skripsi] Jurusan Kesehatan Lingkungan Politeknik Kesehatan DepKes Manado.

Londah, F. 2009. Karakteristik Bakteri Resisten Merkuri di Teluk Manado. [Skripsi] Fakultas Kedokteran Universitas Sam Ratulangi Manado.

Wardhana, W.A. 1994. Dampak Pencemaran Lingkungan. Penerbit Andi, Jogjakarta.

Noviani, R. dan Gusrizal. 2004. Bakteri Resisten Merkuri Spektrum Sempit dari Daerah Bekas Penambangan Emas Tanpa Izin (PETI) Mandor, Kalimantan Barat. [Skripsi] Jurusan Kimia, FMIPA, Universitas Tanjungpura. 